\title{
A Case of Epithelioid Hemangioendothelioma of the Nasal Cavity
}

\author{
Eung Ho Kim, Min Ho Yoon, and Nam-Kyung Yeo \\ Department of Otorhinolaryngology, Gangneung Asan Hospital, University of Ulsan College of Medicine, Gangneung, Korea
}

\section{비강에 발생한 상피모양 혈관내피종 1 예}

김응호 · 윤민호 · 여남경

울산대학교 의과대학 강릉아산병원 이비인후과학교실

\author{
Received June 18, 2015 \\ Revised August 12, 2015 \\ Accepted August 13, 2015 \\ Address for correspondence \\ Nam-Kyung Yeo, MD, PhD \\ Department of Otorhinolaryngology, \\ Gangneung Asan Hospital, \\ University of Ulsan \\ College of Medicine, \\ 38 Bangdong-gil, Socheon-myeon, \\ Gangneung 25440, Korea \\ Tel +82-33-610-3308 \\ Fax +82-33-610-4960 \\ E-mail newnew1@hanmail.net
}

Epithelioid hemangioendothelioma (EHE), a rare vascular tumor that is both clinically and histologically an intermediate between angiosarcoma and hemangioma, was first described by Sharon Weiss and Franz Enzinger. It is characterized by proliferation of a distinct type of endothelial cells, which exhibit epithelioid morphology. It typically occurs in the $20-40$ age range with no sex predilection, although the overall age range involved is much broader. This indolent tumor is potentially recurrent, but it rarely metastasizes. There are very few cases of EHE of nasal cavity described in the English literature. We describe here a case of EHE on the left middle turbinate of a 17-year-old male who presented with history of intermittent epistaxis.

Korean J Otorhinolaryngol-Head Neck Surg 2016;59(3):242-5

Key Words Epithelioid hemangioendothelioma - Nasal cavity.

\section{서 론}

상피모양 혈관내피종(epithelioid hemangioendothelioma) 은 혈관에 분포하는 드문 종양으로, Weiss와 Enzinger ${ }^{1}$ 에 의 해 처음으로 명명되었다. 이 종양은 혈관 내피세포에서 기원하 며, 혈관종과 혈관육종 사이의 중등도의 악성도를 보인다.1) 상 피모양 혈관내피종은 주로 상, 하지, 간, 폐 및 골격에서 발생 하고 두경부에서는 매우 드물게 나타나는데, 두경부에서는 연 부조직이 많은 경부의 악하선 주변에서 가장 많이 발생하는 것으로 보고되어 있으며 비강에서의 사례는 매우 희박하다고 볼 수 있다. ${ }^{2,3}$ 본 저자들은 간헐적인 비출혈을 주소로 내원하 였다가 좌측 비강 내에 발병한 상피모양 혈관내피종으로 진단 받은 환자 1 예를 문헌 고찰과 함께 보고하는 바이다.

\section{증 례}

17 세 남자 환자가 2 개월간 지속된 좌측 비강에서의 간헐적
비출혈을 주소로 내원하였다. 환자의 과거력 및 가족력의 특 이 소견은 없었다. 출혈은 5 분 이내에 멈췄으며 비출혈 이외의 다른 증상은 없었다. 비강내시경 검사에서 좌측 중비갑개 외 측면에 $1 \times 1 \mathrm{~cm}$ 크기의 혈병(blood clot)을 동반한 구형의 회 적색 종괴가 관찰되었으며(Fig. $1 \mathrm{~A}$ ), 비중격 만곡이나 비강 점 막의 미란 등 비출혈의 원인이 될 만한 다른 소견은 관찰되지 않았다. 부비동 컴퓨터단층촬영상 중비갑개 외측 및 중비도에 서 조영 증강이 되지 않는, 육안 소견과 같은 크기의 연부 조 직 소견이 관찰되었다(Fig. 2). 비강 및 주변 조직에서 전이를 의심할 만한 침습소견은 관찰되지 않았다. 이에 비강 내시경 을 이용한 좌측 부분 중비갑개 절제술이 국소 마취 하에 시행 되었으며, 종괴를 포함해서 $5 \mathrm{~mm}$ 이상의 안전 경계를 둔 완 전 절제가 이루어졌다(Fig. 3). 조직 검사상 $\mathrm{H}-\mathrm{E}$ 염색에서 경 계가 분명한 혈관중심성 종양으로 절제 부위의 안전 경계가 확보되었으며, 현미경상 내피세포의 과형성 및 세포 내부에 풍부한 호산구성 세포질과 공포가 관찰되었다(Fig. 4). 또한 면역염색상 CD34 양성, HHV8 음성 소견을 보였다(Fig. 4C). 

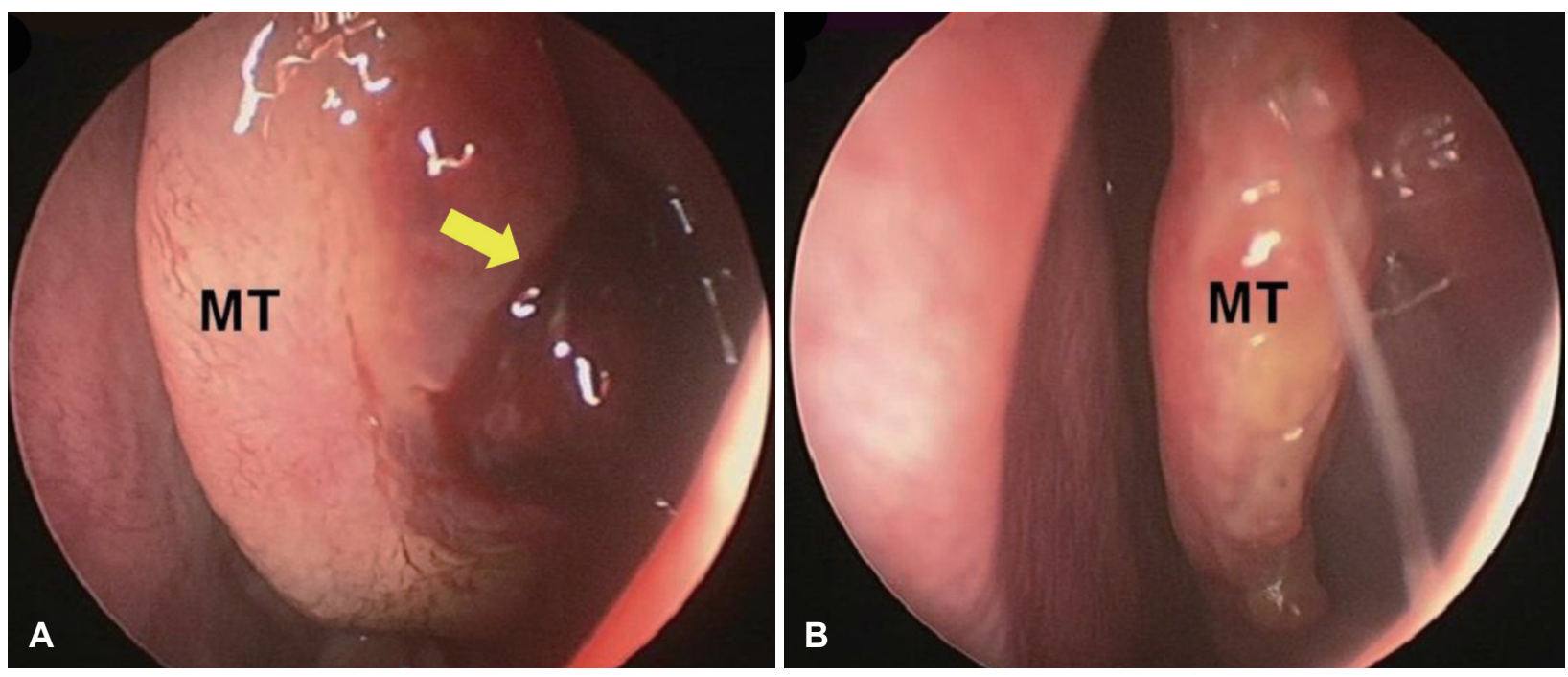

Fig. 1. Preoperative findings $(A)$ shows about $1 \mathrm{~cm}$ sized, globular, red mass on the lateral border of left middle turbinate (arrow). Postoperative findings (POD $3 \mathrm{~m}$ ) (B) shows the wound has healed well. MT: middle turbinate, POD: postoperative days.

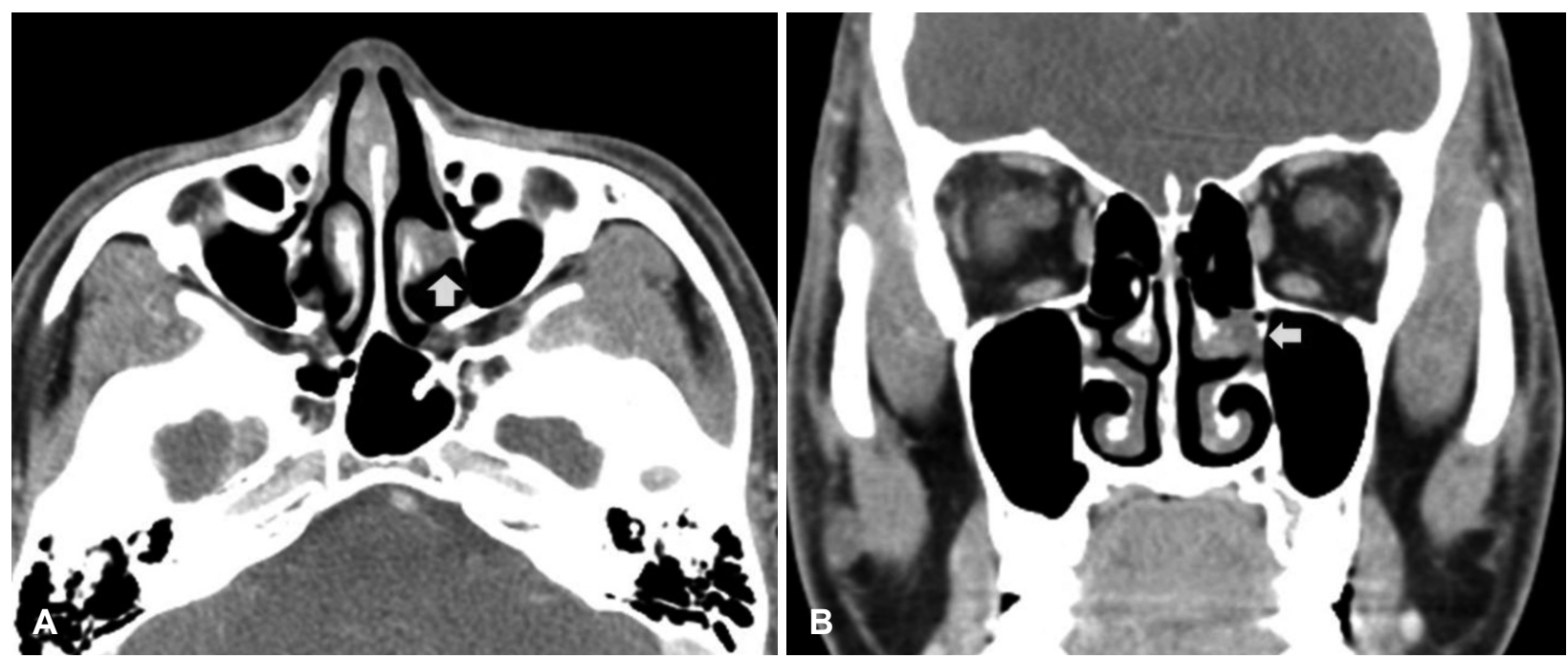

Fig. 2. Axial (A) and coronal (B) there was $0.5 \times 0.7$ sized, non-enhanced soft tissue density on lateral border of left middle turbinate (arrow).
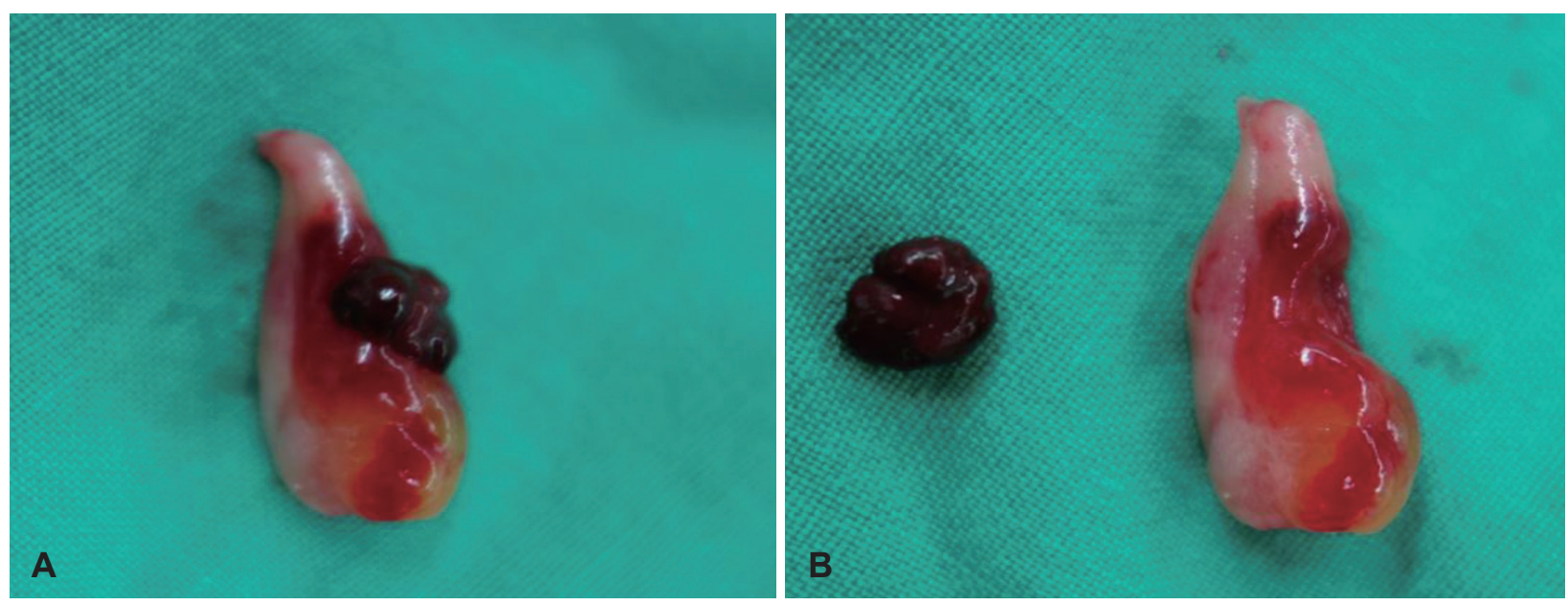

Fig. 3. The tumor and circumjacent middle turbinate were removed (A). The tumor was easily seperated from the middle turbinate (B). 

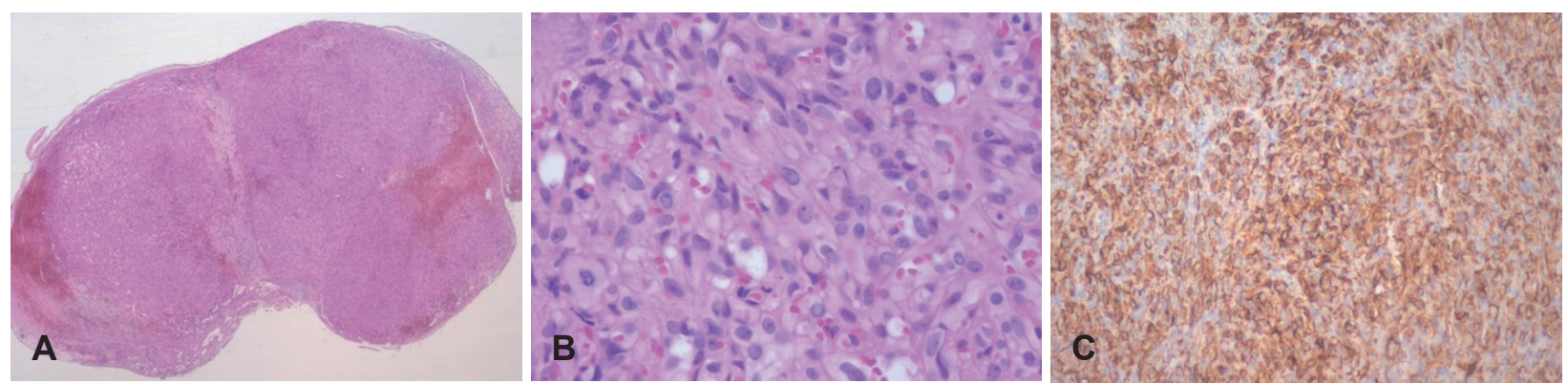

Fig. 4. The tumor appeared as well-demarcated hemorrhagic mass $(H \& E, \times 20)(A)$. The tumor was composed of solid nests of rounded to slightly spindled endothelial cells which have low nuclear grade. The tumor cells formed small intracellular lumens, which were seen as clear spaces, or vacuoles $(\mathrm{H} \& \mathrm{E}, \times 400)(\mathrm{B})$. The tumor cells had positivity for CD34 marker in immunohistochemical study $(\times 200)(\mathrm{C})$.

이에 상피모양 혈관내피종으로 진단하였으며, 환자는 수술 당 일에 바로 퇴원하였다. 추가적인 항암화학치료는 시행하지 않 았으며, 환자는 수술 후 10 개월이 지난 현재까지 별다른 합병 증 없이 추적 관찰 중이다(Fig. 1B).

\section{고 찰}

상피모양 혈관내피종은 혈관의 내피에서 기원하며, 주로 정 맥에서 발생하고, 혈관종과 혈관육종 사이의 중간 정도의 악 성도를 가진 종양이다. ${ }^{1)}$ 상피모양 혈관내피종은 내피세포의 상피모양 형태 및 점액성 세포질 때문에 전이성 종양 및 기타 악성 종양으로 오인받았으며 면역화학염색 및 전자현미경의 발달에 따라 정확한 진단이 가능해졌다. Weiss와 Enzinger ${ }^{1)}$ 가 최초로 보고하기 전에는 맥관성 종양, 조직구종성 혈관 종, 또는 단순히 혈관내피종 등으로 명명되어 왔으며, 1975년 Dail 등근 폐에서 발생한 상피모양 혈관내피종을 상피 종양 (epithelial neoplasm)으로 보고하였으나, 1983년에 내피 종양 (endothelial neoplasm)으로 정정하였다.

남녀의 발생 빈도의 차이는 없는 것으로 알려져 있으며 어 떤 연령에서도 발생 가능하나 아동기에는 비교적 드물다.1) 연 부 조직에서 발생할 경우에 주로 단일성의 종괴로 나타나며, 통증이 수반될 수 있다. 현미경상 종양은 상피모양이나 조직 구형의 내피세포의 증식으로 특징지어지며, 구형, 방추형의 내 피세포가 둥지 또는 짧은 끈 모양의 증식을 보인다. 대부분의 경우 세포는 저등급의 핵 분화도를 보이며, 크거나 분명한 혈 관의 형성은 드물지만 대신 세포질 내부에 공포를 형성하는 특징이 있다. 또한 점액유리질 내에서 분포하는 풍부한 호산 성 세포질을 갖는다.) 때때로 두드러진 세포충실성 및 유사분 열의 수에 따라 악성 종양으로 오인되기도 하며, 이때 이 종양 의 정확한 진단을 위해서는 면역화학적 소견 및 조직병리학적 소견의 연관성이 가장 중요하다. ${ }^{5)}$ 면역조직화학적염색을 통해 $\mathrm{CD} 31, \mathrm{CD} 34$, vimentin 그리고 factor VIII RA와 ulex europeus 등에 양성반응을 보이면 내피세포 기원의 종양임을 확
인할 수 있다.5)

비강에서의 상피모양 혈관내피종은 굉장히 드물어서 2003 년부터 현재까지 5예 이하의 사례만이 보고되어 있으며, 상악 동 내에서 기원된 상피모양 혈관내피종의 사례가 2건 보고되 어 있다. ${ }^{6-10)}$ 두경부에서의 발생도 비교적 드문 편이나 주로 악 하선 주변, 이상선, 구강 내에 잇몸, 혀, 구개점막에서 발생하 는 것으로 보고되었고 비부비동에서 발생하는 경우는 매우 드물다. ${ }^{10)}$ 국내에서는 비중격에 발생한 혈관내피종이 1예가 보 고되어 있으나 혈관 내피종의 아형 중 상피모양(epitheloid)에 는 해당하지 않았고, 병리 조직학적으로 여러 가지의 성분이 섞여 있는 혼합(composite) 혈관내피종 증례의 형태로 보고되 었으며, 더구나 비중격 외 비강 내 타 구조물에 대한 사례는 보 고된 바 없다. ${ }^{11}$

상피모양 혈관내피종이 비강에서 발생한 경우 환자들의 대 부분은 간헐적인 비출혈을 주소로 내원하는 경우가 많았으며, 비강 내시경상 출혈성 경향을 보이는 붉은 종괴의 형태로 보 이는 경우가 많아서 임상적으로 혈관종, 소엽성 모세혈관 혈 관종, 과오종등 출혈성 경향을 보이는 다른 양성 종양과 감별 하기 힘들다. ${ }^{6-9)}$ 정확한 진단은 조직병리 및 면역화학적 염색 에 의존하게 되는데, 조직학적으로도 상피모양의 형태 때문에 전이성 암종 혹은 흑색종 및 다양한 육종들과 감별이 꼭 필요 하다. ${ }^{8}$ 전이성 암종이나 흑색종이 연부 조직으로 전이된 경우, 핵의 이형성 및 유사분열의 수가 상대적으로 많으며 혈관중심 성이 약하다.4) 이외에도 상피모양 혈관종, 악성 상피모양 혈관 내피종, 혈관육종 등의 상피모양 혈관 종양들이 감별진단에 포함된다. ${ }^{7)}$ 상피모양 혈관종은 소엽으로 구분되며, 특징적으 로 명확히 형성된 혈관 내피세포의 tombstone appearance를 보인다. 악성 상피모양 혈관내피종은 정확한 진단의 기준이 없 으나, 종양의 크기가 $3 \mathrm{~cm}$ 이상이면서 $50 \mathrm{HPF}$ 에서 3 개 이상 의 유사분열이 있을 경우에 강하게 의심할 수 있다. 상피모양 혈관육종은 전형적으로 고등급 종양이며 둥근 핵과 두드러진 핵소체, 증가된 유사 분열 활동과 흔한 괴사 소견이 관찰된다.

상피모양 혈관내피종은 임상적, 조직학적으로 경계악성을 
보인다. Deyrup 등 ${ }^{12)}$ 에 의한 연구에서 상피모양 혈관내피종 환 자 49명의 평균 5년 생존율은 $81 \%$ 였으며, 이는 연부조직 혈관 육종의 1 년 내 사망률이 거의 $50 \%$ 인 것과 비교된다. 이 종양 은 국소 혹은 원격 전이가 가능하며, 폐와 림프절이 가장 흔한 전이 장소로 알려져 있다. ${ }^{2)}$ 따라서, 국소적인 상피모양 혈관내 피종의 치료는 경계를 남기지 않는 완전한 절제이다. ${ }^{13)}$ 본 증례 에서도 다른 출혈성 양성 종양과는 달리 종괴 주변으로 $5 \mathrm{~mm}$ 이상의 충분한 안전경계를 두고 절제되었기 때문에 상피모양 혈관내피종이라는 최종적인 조직검사 결과에서도 추가적인 치 료를 시행하지 않을 수 있었다고 본다. 하지만, 조직의 괴사나 핵의 이형성이 심한 경우, 유사분열의 수가 많을 경우 등 악성 화를 시사하는 소견에서 보조적인 항암화학요법이 필요할 수 있다. ${ }^{13)}$ 또한 두경부에서 때때로 완전한 절제가 이루어지지 않 는 경우에 추가적인 방사선 치료를 고려해 볼 수 있다. ${ }^{2)}$ 이 종 양은 재발하는 경향 때문에 장기적인 추적관찰이 필요하며, 드물지만 림프절의 전이의 가능성을 배제하기 위해 임상적으 로 의심될 경우 림프절에 대한 평가도 필요할 수 있다. ${ }^{13)}$

저자들은 국내뿐만 아니라 전 세계적으로 드물게 보고되고 있는 비강 내 상피모양 혈관내피종의 증례가 새롭게 추가되었 다는 사실 이외에도, 비강에서 발생할 수 있는 다른 출혈성 양 성 종양과는 달리 크기가 작음에도 불구하고 잦은 국소 재발 과 전이를 보일 수 있어 충분한 안전 경계를 포함한 완전절제 와 꾸준한 경과 관찰이 필요하다는 면에서 상피모양 혈관내피 종의 임상적인 의의가 있다고 사료되어 문헌 고찰과 함께 보 고하는 바이다.

\section{REFERENCES}

1) Weiss SW, Enzinger FM. Epithelioid hemangioendothelioma: a vascular tumor often mistaken for a carcinoma. Cancer 1982;50 (5):970-81.

2) Bollinger BK, Laskin WB, Knight CB. Epithelioid hemangioendothelioma with multiple site involvement. Literature review and observations. Cancer 1994;73(3):610-5.

3) Mohtasham N, Kharrazi AA, Jamshidi S, Jafarzadeh H. Epithelioid hemangioendothelioma of the oral cavity: a case report. J Oral Sci 2008;50(2):219-23.

4) Dail DH, Liebow AA, Gmelich JT, Friedman PJ, Miyai K, Myer W, et al. Intravascular, bronchiolar, and alveolar tumor of the lung (IVBAT). An analysis of twenty cases of a peculiar sclerosing endothelial tumor. Cancer 1983;51(3):452-64.

5) Mentzel T, Beham A, Calonje E, Katenkamp D, Fletcher CD. Epithelioid hemangioendothelioma of skin and soft tissues: clinicopathologic and immunohistochemical study of 30 cases. Am J Surg Pathol 1997;21(4):363-74.

6) Patnayak R, Jena A, Reddy MK, Chowhan AK, Rao LC, Rukhamangadha N. Epithelioid hemangioendothelioma of nasal cavity. J Lab Physicians 2010;2(2):111-3.

7) Naqvi J, Ordonez NG, Luna MA, Williams MD, Weber RS, ElNaggar AK. Epithelioid hemangioendothelioma of the head and neck: role of podoplanin in the differential diagnosis. Head Neck Pathol 2008;2(1):25-30.

8) Tseng CC, Tsay SH, Tsai TL, Shu CH. Epithelioid hemangioendothelioma of the nasal cavity. J Chin Med Assoc 2005;68(1):45-8.

9) Di Girolamo A, Giacomini PG, Coli A, Castri F, de Padova A, Bigotti G. Epithelioid haemangioendothelioma arising in the nasal cavity. J Laryngol Otol 2003;117(1):75-7.

10) Avadh ani V, Loftus PA, Meltzer D, Wang B, Tabaee A. Epithelioid Hemangioendothelioma of the Maxillary Sinus. Head Neck Pathol 2015 May 12 [Epub ahead of print]. http://dx.doi.org/10.1007/ s12105-015-0633-1.

11) Yang YJ, Kim YB, Kim SB, Sohn JH. A case of hemangioendothelioma on the nasal septum. Korean J Otolaryngol-Head Neck Surg 2001;44 (11):1220-3.

12) Deyrup AT, Tighiouart M, Montag AG, Weiss SW. Epithelioid hemangioendothelioma of soft tissue: a proposal for risk stratification based on 49 cases. Am J Surg Pathol 2008;32(6):924-7.

13) Resnik KS, Kantor GR, Spielvogel RL, Ryan E. Cutaneous epithelioid hemangioendothelioma without systemic involvement. Am J Dermatopathol 1993;15(3):272-6. 